\title{
Hepatic steatosis in HCV-infected persons in the direct-acting antiviral era
}

\author{
Heather L. Stevenson ${ }^{1}$ and Netanya S. Utay ${ }^{2^{*}}$
}

\begin{abstract}
Hepatitis C virus (HCV) infects 130-170 million people worldwide. Recently, direct-acting antivirals have been shown to eradicate HCV infection in 90-95\% of non-cirrhotic patients depending on genotype, treatment experience, and regimen used. Similar rates are achieved among compensated cirrhotics, although longer treatment duration and/ or ribavirin may be required. HCV uses host lipid metabolism for its lifecycle and can cause hepatic steatosis and insulin resistance. Hepatic steatosis, defined as excessive triglyceride deposition in hepatocytes, affects approximately half of HCV-infected individuals. Genetic factors and co-morbidities can drive further steatosis, which in turn can instigate fibrosis and progression to cirrhosis and hepatocellular carcinoma. Polymorphisms in genes that modulate lipid deposition in hepatocytes such as patatin-like phospholipase domain-containing protein 3 (PNPLA3) and transmembrane six superfamily member 2 (TM6SF2) predispose people to steatosis. Metabolic syndrome, obesity, and insulin resistance are increasing worldwide and further contribute to hepatic steatosis, and alcohol has long been recognized as a cause of lipid deposition in the liver. HIV and antiretroviral drugs, but not $\mathrm{HBV}$, may further drive hepatic steatosis. While many of these factors limit response to interferon-based regimens for treating HCV, responses to direct-acting antivirals appear not to be impaired. The effect of HCV eradication on hepatic steatosis and progression to fibrosis, cirrhosis, and hepatocellular carcinoma warrants further study in the era of direct-acting antivirals.
\end{abstract}

Keywords: HCV, HIV, Hepatic steatosis, NAFLD, Metabolic syndrome, Cirrhosis, Direct-acting antivirals

\section{Background}

Hepatitis C virus (HCV) infects $130-170$ million people worldwide, close to $3 \%$ of the world's population [1]. Approximately $80 \%$ develop chronic viral hepatitis, which can progress to liver fibrosis, cirrhosis, and hepatocellular carcinoma (HCC). Recently, interferon (IFN)-free directacting antiviral regimens have been developed for $\mathrm{HCV}$ treatment. Despite their cost, these direct-acting antiviral regimens are now the treatment of choice for all $\mathrm{HCV}$ genotypes. Sustained virologic response (SVR) at 12 weeks (SVR12), i.e., undetectable HCV RNA levels 12 weeks after completing treatment, is achieved in $90-95 \%$ of non-cirrhotics, depending on genotype, treatment experience, and regimen used [2-4]. Comparable responses can be achieved in cirrhotics, but an extended treatment duration and/or ribavirin may be required based on the

\footnotetext{
*Correspondence: neutay@utmb.edu

${ }^{2}$ Division of Infectious Diseases, Department of Medicine, University of Texas

Medical Branch, 301 University Blvd, Galveston, TX 77555, USA

Full list of author information is available at the end of the article
}

regimen [2]. However, SVR12 may be achieved in only $80-85 \%$ of decompensated cirrhotics with most regimens, although newer options approach SVR rates of $95 \%[2,4-7]$.

HCV-infected persons with superimposed conditions such as human immunodeficiency virus (HIV) infection or hepatic steatosis progress to fibrosis and cirrhosis more often and more quickly $[8,9]$. In the IFN era, many of these co-morbidities compromised treatment success. Now, with $\mathrm{HCV}$ eradication possible in virtually everyone, the sequelae of steatosis and its drivers will garner more attention. Here, we explore the drivers of hepatic steatosis in persons infected with $\mathrm{HCV}$ and how these factors may contribute to clinical outcomes.

\section{HCV and steatosis}

Approximately $40-80 \%$ of HCV-positive patients that are biopsied have steatosis, defined as excessive triglyceride deposition in hepatocytes $[10,11]$. The prevalence of hepatic steatosis has a strong genotype dependence, $[12,13]$ 
and genotype 3 infection is now widely accepted as an independent cause of steatosis. Increased severity of hepatic steatosis correlates with higher viral loads, and genotype 3-associated steatosis resolves after SVR with antiviral treatment $[12,14]$. Although HCV genotype 3 infection is independently associated with accelerated fibrosis progression [15] and increased risk for HCC, the steatosis associated with genotype 3 has not been shown to increase these complications.

While genotype 3 patients have increased fibrosis progression, enhanced risk of HCC development, and lower SVR rates with direct-acting antivirals, genotype 1 patients with steatosis may also be at risk for poorer clinical outcomes. This steatosis is likely not mediated solely by HCV. Thus, SVR may not rectify the accelerated hepatic injury and increased fibrosis progression, although some recent studies have shown improvement in lipid profiles following successful HCV treatment in genotype 1 patients [16].

Hepatic steatosis in $\mathrm{HCV}$-infected persons can also be caused by the same host factors that contribute to steatosis in $\mathrm{HCV}$-uninfected persons, such as metabolic syndrome, increased body mass index (BMI), hypertriglyceridemia, chronic alcohol use, other infections, or exposure to certain medications [17]. Unlike steatosis caused by genotype 3 , steatosis caused by metabolic syndrome or insulin resistance is associated with accelerated fibrosis progression, decreased response to IFN-based treatment regimens, and increased risk for HCC [15].

In many people both viral- and host-mediated factors likely contribute to the development of hepatic steatosis. Indeed, HCV replication relies on host lipid metabolism for its lifecycle and results in hepatic steatosis by several mechanisms such as enhancing lipogenesis, impairing mitochondrial lipid oxidation, and downregulating microsomal triglyceride transfer protein (MTTP) activity [18-20]. Thus, steatosis itself may enhance HCV replication, which has been shown to occur in alcohol-altered lipid metabolism [21].

\section{Metabolic syndrome}

Obesity results in increased accumulation of fat, primarily triglycerides, which are synthesized from glycerol and long chain fatty acids (LCFA). LCFA enter hepatocytes via specific, facilitated transport processes, which are regulated in obesity at least in part by insulin, leptin, and spexin [22]. The metabolism of the increased cellular triglyceride content may lead to cell-specific lipotoxicity, contributing to several comorbidities, including hepatic steatosis, non-alcoholic fatty liver disease (NAFLD), and non-alcoholic steatohepatitis (NASH). Overall, in obesity the development of hepatic steatosis is due to too many triglycerides entering the liver via increased LCFA uptake and synthesis, increased triglyceride uptake and synthesis, and too little being removed due to decreased ApoB100 synthesis, decreased triglyceride mobilization, and decreased VLDL assembly and secretion [22].

The most frequent causes of hepatic steatosis in persons that are infected with genotypes other than type 3 , include increased BMI and visceral obesity [23-25]. These two factors provide strong evidence that insulin resistance is the primary pathologic mechanism that leads to abnormal lipid accumulation within hepatocytes. However, it is difficult to determine if the insulin resistance is entirely host-driven, due to $\mathrm{HCV}$ infection, or a combination [20, 26-28]. With the increasing incidence of NAFLD and non-alcoholic steatohepatitis (NASH) in the HCVinfected population, underlying host factors are commonly superimposed on chronic HCV infection. HCV itself has been shown to increase insulin resistance, and insulin resistance increases with increasing viral load and decreases after HCV treatment [29-31]. Based on in vitro experiments, $\mathrm{HCV}$ core protein may increase insulin resistance by down-regulation of glucose transporter 2 (GLUT2), which is responsible for transportation of glucose to hepatocytes. TNF-alpha pathways have also been shown to be involved in insulin receptor substrate inhibition, leading to possible GLUT4 inhibition and decreased uptake of glucose from hepatocytes and other cells [32-35]. Just as for insulin resistance, it is difficult to determine the extent to which host factors are responsible for the development of diabetes mellitus in $\mathrm{HCV}$-infected individuals versus the amount the viral infection itself contributes. Regardless, there is now convincing evidence that $\mathrm{HCV}$ infection increases the risk of developing diabetes, which then increases the risk of developing hepatic steatosis [20].

\section{Genetic predisposition to steatosis in HCV infection}

Several genes have recently been identified as predisposing factors for hepatic steatosis, including in the setting of $\mathrm{HCV}$ infection. Patatin-like phospholipase domain-containing protein 3 (PNPLA3), a lipase that may mediate lipid deposition in hepatocytes and adipocytes [36, 37], is perhaps the best described of these factors. Increased PNPLA3 expression is associated with steatosis, with higher levels correlating with greater severity [38]. The rs738409 (C-> G) I148M polymorphism is associated with increased risk of NAFLD and progression of NAFLD to NASH and cirrhosis in HCV-uninfected persons [39-41]. This polymorphism is also associated with steatosis, steatohepatitis and fibrosis in HCV-infected persons [42-44], even after adjusting for age, sex, body mass index and diabetes [45]. Transmembrane six superfamily member 2 (TM6SF2) likewise modulates triglyceride deposition in hepatocytes. The rs58542926 (A-> G) E167K polymorphism in TM6SF2 is associated with 
increased steatosis in persons with chronic HCV infection [46], albeit to a lesser extent than the PNPLA3 polymorphism [47], and increased hepatic steatosis, steatohepatitis, and fibrosis in NAFLD [46, 48]. Increased hepatic steatosis and fibrosis on biopsy of HIV/HCV co-infected patients were also associated with polymorphisms in the Fat Mass and Obesity-Associated Protein (FTO) gene, which may influence food consumption [49]. Among the Chinese Han population, ApoC3 polymorphisms correlated with higher hepatic and circulating triglyceride levels and subsequently increased risk of NAFLD [50], and among diabetic Taiwanese participants, a polymorphism of the adiponectin gene rendering lower levels was associated with increased risk of NAFLD [51]. In contrast, polymorphisms resulting in increased concentrations of uncoupling protein 2 (UCP2), which modulates reactive oxygen species production, confers a decreased risk of NASH [52]. In sum, numerous genetic factors may predispose people with and without $\mathrm{HCV}$ infection to hepatic steatosis.

\section{HCV and alcohol}

The development of hepatic steatosis due to chronic alcohol exposure involves several complex metabolic pathways including the alcohol dehydrogenase (ADH) pathway, microsomal ethanol-oxidizing system (MEOS), peroxisome proliferator-activated receptor- $\alpha$ (PPAR- $\alpha$ ) and PPAR- $\gamma$, AMP activated protein kinase (AMPK), sterol regulatory element-binding proteins (SREBPs), endoplasmic reticulum stress and methionine metabolism, and mitochondrial abnormalities and lipid peroxidation [53]. Both acute and chronic alcohol use result in increased production of reactive oxygen species (ROS) and reductions in the levels of antioxidants, which is partly mediated by the intermediate product of ethanol metabolism, aldehyde. Due to increased activity of these various metabolic pathways, oxygen requirement by hepatocytes is increased, leading to ischemia and centrilobular liver necrosis. In addition, steatotic hepatocytes are more susceptible to ischemic injury [54].

Cytokines produced by adipocytes and inflammatory cells including Kupffer cells, such as adiponectin, leptin, TNF- $\alpha$, and IL- 6 , also play a role in the pathogenesis of alcohol-mediated liver disease and NASH [53]. Through many interactions, including with PPAR- $\alpha$ and PPAR- $\gamma$, adiponectins decrease lipid synthesis and increase lipolysis. Whether alcohol results in decreased adiponectin levels remains controversial [55, 56]. Leptin increases CD14 expression on Kupffer cells and activates hepatic stellate cells, promoting hepatic inflammation and fibrosis, respectively [57]. Alcohol also increases the permeability of the gut barrier, leading to increased endotoxemia, and changes the intestinal microbiome [58, 59], which further enhances cytokine production and activation of hepatic inflammatory cells and stellate cells.

There is an increased prevalence of $\mathrm{HCV}$ infection in alcoholics $[60,61]$ and liver injury appears to be more severe in HCV-infected persons with steatohepatitis. People infected with HCV that are heavy drinkers have accelerated fibrosis progression and are at higher risk of developing HCC [62, 63]. Several factors have been implicated in potentiating the effects of alcohol exposure in HCV-infected persons, which includes impaired antiviral immunity, increased viral replication, increased oxidative stress, increased iron overload, and steatosis.

\section{Contribution of chronic HBV and HIV co-infections to steatosis}

Approximately 2.75 million people worldwide have HIV$\mathrm{HCV}$ co-infection and 2.6 million have HBV-HCV coinfection [64]. HIV infection accelerates the progression of HCV to cirrhosis [65], but HIV's contribution to steatosis has only been recognized recently. NAFLD affects 13-50 \% of HIV-infected persons [66-68]. In a study of 30 HIV-infected participants with unexplained elevated transaminases, $72 \%$ had steatosis and/or fibrosis, $53 \%$ had NASH, and $63 \%$ had fibrosis [69]. HIV-HCV coinfected participants have a higher rate of steatosis than either mono-infected group in some studies [70-73]. Potential contributing factors may include dyslipidemia and insulin resistance due to HIV and/or antiretrovirals, obesity, sedentary lifestyle, and increased systemic inflammation [9, 74, 75]. Older antiretrovirals such as stavudine appear more likely to contribute to steatosis than the more commonly used agents today [75]. In addition, decreased adiponectin with HIV infection may contribute to the increased steatosis [76]. Thus, lipid deposition in the liver is increased in HIV infection.

HIV-infected people with NAFLD are also more likely to develop steatohepatitis [77]. HIV can directly infect Kupffer cells, although these data are controversial [78]. Regardless, HIV may increase the population, proliferation, and turnover of Kupffer cells in the liver, resulting in a pro-inflammatory state [78]. HIV infection is associated with increased translocation of microbial products from a permeable intestinal barrier [79] through the portal circulation to the liver, where they are phagocytosed by Kupffer cells and may drive further hepatic inflammation [80]. The mitochondrial dysfunction induced by HIV and antiretrovirals induces reactive oxygen species production, causing additional hepatic damage [81]. The overall suppression of regulatory $\mathrm{T}$ cell pathways by HIV infection may also inhibit modulation of this inflammatory state [9]. Ultimately, HIV accelerates progression to cirrhosis in $\mathrm{HCV}$-infected persons, particularly in the presence of steatosis $[65,82]$. 
HBV increases the rate of progression to cirrhosis and hepatocellular carcinoma in HCV-infected persons [83], but whether $\mathrm{HBV}$ can contribute to hepatic steatosis remains controversial. The $\mathrm{HBV}$ protein $\mathrm{HBx}$, which facilitates HBV replication [84], induces hepatic steatosis and fatty acid oxidation in mouse models [85, 86]. However, based on a meta-analysis of human studies, hepatic steatosis is less common among HBV-infected compared to HCV-infected persons [72] and is usually found in conjunction with host factors such as hypertriglyceridemia $[72,87]$. Some data suggest that HBV infection may even be associated with a lower risk of steatosis, but this was also in the context of lower triglyceride levels and less metabolic syndrome [88]. Unexpectedly, increased hepatic steatosis is actually associated with lower HBV DNA levels $[72,89]$, but this finding may be explained by the association of PNPLA3 polymorphisms with both steatosis and lower HBV DNA levels [90]. Thus, HBV does not clearly increase the risk of steatosis.

\section{The effect of comorbidities on HCV treatment response}

The direct-acting antiviral agents for HCV infection achieve SVR rates exceeding $95 \%$ for non-cirrhotic patients. Lengthening duration of therapy and/or adding ribavirin can render similar SVR rates in cirrhotics, but with most regimens, SVR rates are about $10 \%$ lower in decompensated cirrhotics [2]. Co-morbidities and concomitant medications may limit regimen options, which could influence SVR rates. Co-morbidities that contribute to cirrhosis by increasing the risk of steatohepatitis may also impact HCV treatment success.

These contributors to steatohepatitis have varying impacts on response rates to $\mathrm{HCV}$ treatment. Whether steatosis alone affects SVR rates to IFN-based regimens in the absence of fibrosis is controversial, and few studies have been done with IFN-free regimens [82, 91-94]. Metabolic syndrome was associated with decreased SVR rates in the IFN era $[95,96]$ but no longer seems to have an effect $[97,98]$. People with HIV infection had lower SVR rates to IFN-based regimens than HIV-uninfected people, $40 \%$ versus $56 \%$ [99], but now HIV-infected persons achieve comparable SVR rates, exceeding $95 \%$ in the absence of cirrhosis [100-102]. HBV does not decrease SVR rates regardless of the treatment regimen. However, HBV and HCV inhibit each other's replication, and consequently, HBV may reactivate with HCV treatment [103-106], with the risk for progression to cirrhosis and HCC. No data demonstrate decreased SVR rates to direct-acting antivirals with alcohol or even illicit substance use [2]. However, binge drinking, illicit substance use and potential complications such as incarceration can interfere with a patient's adherence to antiviral regimens and therefore warrant consideration. Thus, most comorbidities do not appear to directly attenuate responses to direct-acting antiviral treatment, but their contributions to cirrhosis may lower the likelihood of achieving SVR.

\section{Conclusions}

$\mathrm{HCV}$ infection is now a curable disease. However, HCVinfected people have comorbidities that cause steatosis and may continue to damage the liver after HCV eradication, including the increasingly prevalent metabolic syndrome. HCV may contribute to hepatic steatosis and to metabolic syndrome, forming a positive feedback loop that may further increase steatosis and culminate in steatohepatitis and fibrosis. Ultimately, after SVR, fibrosis can regress in some patients [107, 108], but based on data from the IFN era, the presence of these comorbidities may prevent fibrosis regression. Long-term studies in HCVinfected persons treated with direct-acting antivirals will illuminate the degree to which steatosis, steatohepatitis, and/or fibrosis reverse with SVR, particularly with persistence of other comorbidities. In sum, comorbidities may have less of an impact now on SVR with the highly efficacious direct-acting antiviral therapy, but their persistence may prevent complete return to health in $\mathrm{HCV}$-cured patients.

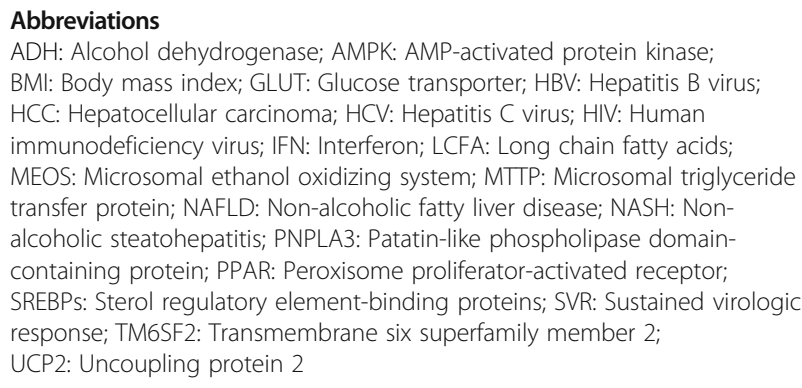

\section{Acknowledgements}

Not applicable.

\section{Funding}

Moody Endowment (HSL)

\section{Availability of data and materials}

Not applicable.

\section{Authors' contributions}

HSL and NSU wrote and edited the manuscript. Both HSL and NSU read and approved the manuscript.

\section{Authors' information \\ HSL is a liver pathologist. NSU is an infectious diseases physician who treats HCV and HIV infections.}

\section{Competing interests}

The authors declare that they have no competing interests.

Consent for publication

Not applicable.

Ethics approval and consent to participate

Not applicable. 


\section{Author details}

${ }^{1}$ Department of Pathology, University of Texas Medical Branch, 301 University Blvd, Galveston, TX 77555, USA. ²Division of Infectious Diseases, Department of Medicine, University of Texas Medical Branch, 301 University Blvd, Galveston, TX 77555, USA

Received: 18 June 2016 Accepted: 22 September 2016

Published online: 27 September 2016

\section{References}

1. Hajarizadeh B, Grebely J, Dore GJ. Epidemiology and natural history of HCV infection. Nat Rev Gastroenterol Hepatol. 2013;10(9):553-62.

2. AASLD-IDSA. Recommendations for testing, managing, and treating hepatitis C. http://www.hcvguidelines.org. Accessed 31 Aug 2016.

3. Hartman J, Bichoupan K, Patel N, Chekuri S, Harty A, Dieterich D, Perumalswami P, Branch AD. Re-re-treatment of hepatitis $C$ virus: Eight patients who relapsed twice after direct-acting-antiviral drugs. World J Gastroenterol. 2015;21(43):12430-8.

4. Bailly F, Pradat P, Virlogeux V, Zoulim F. Antiviral Therapy in Patients with Hepatitis C Virus-Induced Cirrhosis. Digestive Diseases (Basel, Switzerland). 2015;33(4):613-23

5. Foster GR, Irving WL, Cheung MC, Walker AJ, Hudson BE, Verma S, McLauchlan J, Mutimer DJ, Brown A, Gelson WT, et al. Impact of direct acting antiviral therapy in patients with chronic hepatitis $C$ and decompensated cirrhosis. J Hepatol. 2016;64(6):1224-31.

6. Curry MP, O'Leary JG, Bzowej N, Muir AJ, Korenblat KM, Fenkel JM, Reddy KR, Lawitz E, Flamm SL, Schiano T, et al. Sofosbuvir and Velpatasvir for HCV in Patients with Decompensated Cirrhosis. N Engl J Med. 2015;373(27):2618-28.

7. Kanda T. Interferon-free treatment for HCV-infected patients with decompensated cirrhosis. Hepatol Int. 2016 Jun 9. [Epub ahead of print].

8. Alberti A. What are the comorbidities influencing the management of patients and the response to therapy in chronic hepatitis C? Liver International: Official Journal of the International Association for the Study of the Liver. 2009;29 Suppl 1:15-8.

9. Sacchi P, Cima S, Zuccaro V, Columpsi P, Sarda C, Mariani M, Puoti M, Bruno R. Understanding the Mechanisms of Fibrogenesis in HIV/HCV-Coinfected Patients: Implications for Clinical Practice. AIDS Rev. 2015;17(3):159-70.

10. Del Campo JA, Romero-Gomez M. Steatosis and insulin resistance in hepatitis C: a way out for the virus? World J Gastroenterol. 2009;15(40):5014-9.

11. Asselah T, Rubbia-Brandt $L$, Marcellin P, Negro F. Steatosis in chronic hepatitis C: why does it really matter? Gut. 2006;55(1):123-30.

12. Rubbia-Brandt L, Quadri R, Abid K, Giostra E, Male PJ, Mentha G, Spahr L, Zarski JP, Borisch B, Hadengue A, et al. Hepatocyte steatosis is a cytopathic effect of hepatitis C virus genotype 3. J Hepatol. 2000;33(1):106-15.

13. Rubbia-Brandt L, Leandro G, Spahr L, Giostra E, Quadri R, Male PJ, Negro F. Liver steatosis in chronic hepatitis C: a morphological sign suggesting infection with HCV genotype 3. Histopathology. 2001:39(2):119-24.

14. Rubbia-Brandt L, Giostra E, Mentha G, Quadri R, Negro F. Expression of liver steatosis in hepatitis $C$ virus infection and pattern of response to alphainterferon. J Hepatol. 2001;35(2):307.

15. Bochud PY, Cai T, Overbeck K, Bochud M, Dufour JF, Mullhaupt B, Borovicka J, Heim M, Moradpour D, Cerny A, et al. Genotype 3 is associated with accelerated fibrosis progression in chronic hepatitis C. J Hepatol. 2009:51(4):655-66

16. Meissner EG, Lee YJ, Osinusi A, Sims Z, Qin J, Sturdevant D, McHutchison J, Subramanian M, Sampson M, Naggie S, et al. Effect of sofosbuvir and ribavirin treatment on peripheral and hepatic lipid metabolism in chronic hepatitis $\mathrm{C}$ virus, genotype 1-infected patients. Hepatology (Baltimore, Md). 2015;61(3):790-801.

17. Byrne CD, Targher G. NAFLD: a multisystem disease. J Hepatol. 2015:62(1 Suppl):S47-64

18. Perlemuter G, Sabile A, Letteron P, Vona G, Topilco A, Chretien Y, Koike K, Pessayre D, Chapman J, Barba G, et al. Hepatitis C virus core protein inhibits microsomal triglyceride transfer protein activity and very low density lipoprotein secretion: a model of viral-related steatosis. FASEB Journal: Official Publication of the Federation of American Societies for Experimental Biology. 2002;16(2):185-94

19. Amako Y, Munakata T, Kohara M, Siddiqui A, Peers C, Harris M. Hepatitis C virus attenuates mitochondrial lipid beta-oxidation by downregulating mitochondrial trifunctional-protein expression. J Virol. 2015;89(8):4092-101.
20. Kralj D, Virovic Jukic L, Stojsavljevic S, Duvnjak M, Smolic M, Curcic IB. Hepatitis C Virus, Insulin Resistance, and Steatosis. J Clin Translational Hepatol. 2016;4(1):66-75.

21. Seronello $\mathrm{S}$, Ito $\mathrm{C}$, Wakita T, Choi J. Ethanol enhances hepatitis $\mathrm{C}$ virus replication through lipid metabolism and elevated NADH/NAD+. J Biol Chem. 2010;285(2):845-54.

22. Berk PD, Verna EC. Nonalcoholic Fatty Liver Disease: Lipids and Insulin Resistance. Clin Liver Dis. 2016;20(2):245-62.

23. Adinolfi LE, Gambardella M, Andreana A, Tripodi MF, Utili R, Ruggiero G. Steatosis accelerates the progression of liver damage of chronic hepatitis $C$ patients and correlates with specific HCV genotype and visceral obesity. Hepatology (Baltimore, Md). 2001;33(6):1358-64.

24. Hui JM, Sud A, Farrell GC, Bandara P, Byth K, Kench JG, McCaughan GW, George J. Insulin resistance is associated with chronic hepatitis C virus infection and fibrosis progression [corrected]. Gastroenterology. 2003;125(6):1695-704.

25. Liakina V, Speiciene D, Irnius A, Semuchiniene T, Valantinas J. Association of the prevalence and grade of steatosis in patients with chronic hepatitis C with the host and viral factors. Acta Gastro-Enterol Belg. 2007;70(3):260-6.

26. Negro F. Abnormalities of lipid metabolism in hepatitis $C$ virus infection. Gut. 2010;59(9):1279-87.

27. Negro F. HCV infection and metabolic syndrome: which is the chicken and which is the egg? Gastroenterology. 2012;142(6):1288-92.

28. Negro F. Facts and fictions of HCV and comorbidities: steatosis, diabetes mellitus, and cardiovascular diseases. J Hepatol. 2014;61(1 Suppl):S69-78.

29. Hsu CS, Liu CJ, Liu CH, Chen CL, Lai MY, Chen PJ, Chen DS, Kao JH. Metabolic profiles in patients with chronic hepatitis C: a case-control study. Hepatol Int. 2008;2(2):250-7.

30. Hsu CS, Liu CJ, Liu CH, Wang CC, Chen CL, Lai MY, Chen PJ, Kao JH, Chen DS. High hepatitis $C$ viral load is associated with insulin resistance in patients with chronic hepatitis C. Liver International: Official Journal of the International Association for the Study of the Liver. 2008;28(2):271-7.

31. Moucari R, Asselah T, Cazals-Hatem D, Voitot H, Boyer N, Ripault MP, Sobesky R, Martinot-Peignoux M, Maylin S, Nicolas-Chanoine $\mathrm{MH}$, et al. Insulin resistance in chronic hepatitis C: association with genotypes 1 and 4, serum HCV RNA level, and liver fibrosis. Gastroenterology. 2008;134(2):416-23.

32. Romero-Gomez M. Insulin resistance and hepatitis C. World J Gastroenterol. 2006;12(44):7075-80

33. del Campo JA, Garcia-Valdecasas M, Rojas L, Rojas A, Romero-Gomez M. The hepatitis $C$ virus modulates insulin signaling pathway in vitro promoting insulin resistance. PLoS One. 2012;7(10):e47904.

34. Banerjee S, Saito K, Ait-Goughoulte M, Meyer K, Ray RB, Ray R. Hepatitis C virus core protein upregulates serine phosphorylation of insulin receptor substrate-1 and impairs the downstream akt/protein kinase B signaling pathway for insulin resistance. J Virol. 2008;82(6):2606-12.

35. Banerjee A, Meyer K, Mazumdar B, Ray RB, Ray R. Hepatitis C virus differentially modulates activation of forkhead transcription factors and insulin-induced metabolic gene expression. J Virol. 2010;84(12):5936-46.

36. Lim JW, Dillon J, Miller M. Proteomic and genomic studies of non-alcoholic fatty liver disease-clues in the pathogenesis. World J Gastroenterol. 2014;20(26):8325-40

37. Mehta R, Birerdinc A, Younossi ZM. Host genetic variants in obesity-related nonalcoholic fatty liver disease. Clin Liver Dis. 2014;18(1):249-67.

38. Aragones G, Auquet T, Armengol S, Berlanga A, Guiu-Jurado E, Aguilar C, Martinez S, Sabench F, Porras JA, Ruiz MD, et al. PNPLA3 Expression Is Related to Liver Steatosis in Morbidly Obese Women with Non-Alcoholic Fatty Liver Disease. Int J Mol Sci. 2016;17(5)

39. Xia MF, Ling $Y$, Bian $H$, Lin HD, Yan HM, Chang XX, Li XM, Ma H, Wang D, Zhang LS, et al. I148M variant of PNPLA3 increases the susceptibility to non-alcoholic fatty liver disease caused by obesity and metabolic disorders. Aliment Pharmacol Ther. 2016;43(5):631-42.

40. Xu R, Tao A, Zhang S, Deng Y, Chen G. Association between patatin-like phospholipase domain containing 3 gene (PNPLA3) polymorphisms and nonalcoholic fatty liver disease: a HuGE review and meta-analysis. Sci Rep. 2015:5:9284

41. Vespasiani-Gentilucci U, Gallo P, Porcari A, Carotti S, Galati G, Piccioni L, De Vincentis A, Dell'Unto C, Vorini F, Morini S, et al. The PNPLA3 rs738409 C> G polymorphism is associated with the risk of progression to cirrhosis in NAFLD patients. Scand J Gastroenterol. 2016:51(8):967-73.

42. Fan JH, Xiang MQ, Li QL, Shi HT, Guo JJ. PNPLA3 rs738409 Polymorphism Associated with Hepatic Steatosis and Advanced Fibrosis in Patients with Chronic Hepatitis C Virus: A Meta-Analysis. Gut and liver. 2016;10(3):456-63. 
43. Petta S, Vanni E, Bugianesi E, Rosso C, Cabibi D, Camma C, Di Marco V, Eslam M, Grimaudo S, Macaluso FS, et al. PNPLA3 rs738409 1748M is associated with steatohepatitis in 434 non-obese subjects with hepatitis C. Aliment Pharmacol Ther. 2015;41(10):939-48.

44. Sagnelli C, Merli M, Uberti-Foppa C, Hasson H, Cirillo G, Grandone A, Salpietro S, Minichini C, Del Giudice EM, Lazzarin A, et al. Impact of PNPLA3 variants on liver histology of 168 patients with HIV infection and chronic hepatitis C. Clin Microbiol Infect. 2016;22(4):372-8.

45. Yasui K, Kawaguchi T, Shima T, Mitsuyoshi H, Seki K, Sendo R, Mizuno M, Itoh Y, Matsuda F, Okanoue T. Effect of PNPLA3 rs738409 variant (I148 M) on hepatic steatosis, necroinflammation, and fibrosis in Japanese patients with chronic hepatitis C. J Gastroenterol. 2015;50(8):887-93.

46. Coppola N, Rosa Z, Cirillo G, Stanzione M, Macera M, Boemio A, Grandone A, Pisaturo M, Marrone A, Adinolfi LE, et al. TM6SF2 E167K variant is associated with severe steatosis in chronic hepatitis $C$, regardless of PNPLA3 polymorphism. Liver International: Official Journal of the International Association for the Study of the Liver. 2015;35(8):1959-63.

47. Eslam M, Mangia A, Berg T, Chan HL, Irving WL, Dore GJ, Abate ML, Bugianesi E, Adams LA, Najim MA, et al. Diverse impacts of the rs58542926 E167K variant in TM6SF2 on viral and metabolic liver disease phenotypes. Hepatology. 2016;64(1):34-46.

48. Liu YL, Reeves HL, Burt AD, Tiniakos D, McPherson S, Leathart JB, Allison ME, Alexander GJ, Piguet AC, Anty R, et al. TM6SF2 rs58542926 influences hepatic fibrosis progression in patients with non-alcoholic fatty liver disease. Nat Commun. 2014;5:4309.

49. Pineda-Tenor D, Berenguer J, Jimenez-Sousa MA, Garcia-Alvarez M, AldamizEchevarria T, Carrero A, Vazquez-Moron S, Garcia-Broncano P, Diez C, Tejerina F, et al. FTO rs9939609 polymorphism is associated with metabolic disturbances and response to HCV therapy in HIV/HCV-coinfected patients. BMC Med. 2014;12:198

50. Zhang RN, Zheng RD, Mi YQ, Zhou D, Shen F, Chen GY, Zhu CY, Pan Q, Fan JG. APOC3 rs2070666 Is Associated with the Hepatic Steatosis Independently of PNPLA3 rs738409 in Chinese Han Patients with Nonalcoholic Fatty Liver Diseases. Digestive Diseases and Sciences. 2016; 61(8):2284-93.

51. Hsieh CJ, Wang PW, Hu TH. Association of adiponectin gene polymorphism with nonalcoholic fatty liver disease in Taiwanese patients with type 2 diabetes. PLoS One. 2015;10(6):e0127521.

52. Fares $R$, Petta $S$, Lombardi $R$, Grimaudo S, Dongiovanni P, Pipitone $R$, Rametta R, Fracanzani AL, Mozzi E, Craxi A, et al. The UCP2-866 G>A promoter region polymorphism is associated with nonalcoholic steatohepatitis. Liver International: Official Journal of the International Association for the Study of the Liver. 2015;35(5):1574-80.

53. Sugimoto K, Takei Y. Pathogenesis of alcoholic liver disease. Hepatology Research: The Official Journal of the Japan Society of Hepatology. 2016 May 3. [Epub ahead of print].

54. Bernstein J, Videla L, Israel Y. Metabolic alterations produced in the liver by chronic ethanol administration. Changes related to energetic parameters of the cell. Biochem J. 1973;134(2):515-21.

55. Song Z, Zhou Z, Deaciuc I, Chen T, McClain CJ. Inhibition of adiponectin production by homocysteine: a potential mechanism for alcoholic liver disease. Hepatology (Baltimore, Md). 2008;47(3):867-79.

56. Tang H, Sebastian BM, Axhemi A, Chen X, Hillian AD, Jacobsen DW, Nagy LE. Ethanol-induced oxidative stress via the CYP2E1 pathway disrupts adiponectin secretion from adipocytes. Alcohol Clin Exp Res. 2012;36(2):214-22.

57. Ikejima K, Okumura K, Lang T, Honda H, Abe W, Yamashina S, Enomoto N, Takei $Y$, Sato N. The role of leptin in progression of non-alcoholic fatty liver disease. Hepatology Research: The Official Journal of the Japan Society of Hepatology. 2005;33(2):151-4

58. Mir H, Meena AS, Chaudhry KK, Shukla PK, Gangwar R, Manda B, Padala MK, Shen L, Turner JR, Dietrich P, et al. Occludin deficiency promotes ethanolinduced disruption of colonic epithelial junctions, gut barrier dysfunction and liver damage in mice. Biochim Biophys Acta. 2016;1860(4):765-74.

59. Engen PA, Green SJ, Voigt RM, Forsyth CB, Keshavarzian A. The Gastrointestinal Microbiome: Alcohol Effects on the Composition of Intestinal Microbiota. Alcohol Research: Current Reviews. 2015;37(2):223-36.

60. Mueller S, Millonig G, Seitz HK. Alcoholic liver disease and hepatitis C: a frequently underestimated combination. World Journal of Gastroenterology: WJG. 2009;15(28):3462-71.

61. Funderburg NT, Mayne E, Sieg SF, Asaad R, Jiang W, Kalinowska M, Luciano AA, Stevens W, Rodriguez B, Brenchley JM, et al. Increased tissue factor expression on circulating monocytes in chronic HIV infection: relationship to in vivo coagulation and immune activation. Blood. 2010;115(2):161-7.

62. Shimizu S, Kiyosawa K, Sodeyama T, Tanaka E, Nakano M. High prevalence of antibody to hepatitis $C$ virus in heavy drinkers with chronic liver diseases in Japan. J Gastroenterol Hepatol. 1992;7(1):30-5.

63. Tsutsumi M, Ishizaki M, Takada A. Relative risk for the development of hepatocellular carcinoma in alcoholic patients with cirrhosis: a multiple logistic-regression coefficient analysis. Alcohol Clin Exp Res. 1996;20(4):758-62.

64. http://www.who.int/hiv/topics/hepatitis/en/. Accessed 5 Oct 2015.

65. Konerman MA, Mehta SH, Sutcliffe CG, Vu T, Higgins Y, Torbenson MS, Moore RD, Thomas DL, Sulkowski MS. Fibrosis progression in human immunodeficiency virus/hepatitis C virus coinfected adults: prospective analysis of 435 liver biopsy pairs. Hepatology (Baltimore, Md). 2014:59(3):767-75.

66. Price JC, Seaberg EC, Latanich R, Budoff MJ, Kingsley LA, Palella Jr FJ, Witt MD, Post WS, Thio CL. Risk factors for fatty liver in the Multicenter AIDS Cohort Study. Am J Gastroenterol. 2014;109(5):695-704.

67. Nishijima T, Gatanaga H, Shimbo T, Komatsu H, Nozaki Y, Nagata N, Kikuchi Y, Yanase M, Oka S. Traditional but not HIV-related factors are associated with nonalcoholic fatty liver disease in Asian patients with HIV-1 infection. PLoS One. 2014;9(1):e87596.

68. Vallet-Pichard A, Mallet V, Pol S. Nonalcoholic fatty liver disease and HIV infection. Semin Liver Dis. 2012;32(2):158-66.

69. Ingiliz P, Valantin MA, Duvivier C, Medja F, Dominguez S, Charlotte F, Tubiana R, Poynard T, Katlama C, Lombes A, et al. Liver damage underlying unexplained transaminase elevation in human immunodeficiency virus-1 mono-infected patients on antiretroviral therapy. Hepatology (Baltimore, Md). 2009;49(2):436-42.

70. Gaslightwala I, Bini EJ. Impact of human immunodeficiency virus infection on the prevalence and severity of steatosis in patients with chronic hepatitis C virus infection. J Hepatol. 2006;44(6):1026-32.

71. Castera L, Loko MA, Le Bail B, Coffie P, De Ledinghen V, Trimoulet P, Winnock M, Dabis F, Neau D. Hepatic steatosis in HIV-HCV coinfected patients in France: comparison with HCV monoinfected patients matched for body mass index and HCV genotype. Aliment Pharmacol Ther. 2007; 26(11-12):1489-98.

72. Machado MV, Oliveira AG, Cortez-Pinto H. Hepatic steatosis in hepatitis B virus infected patients: meta-analysis of risk factors and comparison with hepatitis C infected patients. J Gastroenterol Hepatol. 2011;26(9):1361-7.

73. Li Vecchi V, Giannitrapani L, Di Carlo P, Mazzola G, Colletti P, La Spada E, Vizzini G, Montalto G, Soresi M. Non-invasive assessment of liver steatosis and fibrosis in HIV/HCV- and HCV- infected patients. Ann Hepatol. 2013;12(5):740-8.

74. Macias J, Real LM, Rivero-Juarez A, Merchante N, Camacho A, Neukam K, Rivero A, Mancebo M, Pineda JA. Changes in liver steatosis evaluated by transient elastography with the controlled attenuation parameter in HIVinfected patients. HIV Med. 2016 Mar 29. [Epub ahead of print]

75. Borghi V, Bisi L, Manzini L, Cossarizza A, Mussini C. Absence of liver steatosis in HIV-HCV co-infected patients receiving regimens containing tenofovir or abacavir. Infection. 2013;41(2):425-9.

76. Ndombi EM, Budambula V, Webale MK, Musumba FO, Wesongah JO, Mibei E, Ahmed AA, Lihana R, Were T. Serum adiponectin in HIV-1 and hepatitis C virus mono- and co-infected Kenyan injection drug users. Endocrine Connections. 2015:4(4):223-32

77. Vodkin I, Valasek MA, Bettencourt R, Cachay E, Loomba R. Clinical, biochemical and histological differences between HIV-associated NAFLD and primary NAFLD: a case-control study. Aliment Pharmacol Ther. 2015;41(4):368-78

78. Ahsan MH, Gill AF, Alvarez X, Lackner AA, Veazey RS. Kinetics of liver macrophages (Kupffer cells) in SIV-infected macaques. Virology. 2013;446(1-2):77-85.

79. Sandler NG, Douek DC. Microbial translocation in HIV infection: causes, consequences and treatment opportunities. Nat Rev Microbiol. 2012;10(9):655-66

80. Estes JD, Harris LD, Klatt NR, Tabb B, Pittaluga S, Paiardini M, Barclay GR, Smedley J, Pung R, Oliveira KM, et al. Damaged intestinal epithelial integrity linked to microbial translocation in pathogenic simian immunodeficiency virus infections. PLoS Pathog. 2010;6(8):e1001052.

81. Perez-Matute P, Perez-Martinez L, Blanco JR, Oteo JA. Role of mitochondria in HIV infection and associated metabolic disorders: focus on nonalcoholic 
fatty liver disease and lipodystrophy syndrome. Oxid Med Cell Longev. 2013;2013:493413

82. Lemoine M, Serfaty L, Capeau J. From nonalcoholic fatty liver to nonalcoholic steatohepatitis and cirrhosis in HIV-infected patients: diagnosis and management. Curr Opin Infect Dis. 2012;25(1):10-6.

83. Zarski JP, Bohn B, Bastie A, Pawlotsky JM, Baud M, Bost-Bezeaux F, van Nhieu Tran J, Seigneurin JM, Buffet C, Dhumeaux D. Characteristics of patients with dual infection by hepatitis B and C viruses. J Hepatol. 1998;28(1):27-33.

84. Slagle BL, Bouchard MJ. Hepatitis B Virus X and Regulation of Viral Gene Expression. Cold Spring Harbor Perspectives in Medicine. 2016;6(3):a021402.

85. Wu YL, Peng XE, Zhu YB, Yan XL, Chen WN, Lin X. Hepatitis B Virus X Protein Induces Hepatic Steatosis by Enhancing the Expression of Liver Fatty Acid Binding Protein. J Virol. 2016;90(4):1729-40.

86. Wang MD, Wu H, Huang S, Zhang HL, Qin CJ, Zhao LH, Fu GB, Zhou X, Wang $X M$, Tang $L$, et al. HBx regulates fatty acid oxidation to promote hepatocellular carcinoma survival during metabolic stress. Oncotarget. 2016;7(6):6711-26.

87. Yilmaz B, Koklu S, Buyukbayram H, Yalcin K, Korkmaz U, Posul E, Can G, Kurt M. Chronic hepatitis B associated with hepatic steatosis, insulin resistance, necroinflammation and fibrosis. Afr Health Sci. 2015;15(3):714-8.

88. Wong WW, Wong GL, Chu WC, Chim AM, Ong A, Yeung DK, Yiu KK, Chu SH, Chan HY, Woo J, et al. Hepatitis B virus infection and fatty liver in the general population. J Hepatol. 2012;56(3):533-40.

89. Rastogi A, Sakhuja P, Kumar A, Hissar S, Jain A, Gondal R, Sarin SK. Steatosis in chronic hepatitis B: prevalence and correlation with biochemical, histologic, viral, and metabolic parameters. Indian J Pathol Microbiol. 2011;54(3):454-9.

90. Pan $Q$, Zhang RN, Wang YQ, Zheng RD, Mi YQ, Liu WB, Shen F, Chen GY, Lu $J F$, Zhu CY, et al. Linked PNPLA3 polymorphisms confer susceptibility to nonalcoholic steatohepatitis and decreased viral load in chronic hepatitis B. World J Gastroenterol. 2015;21(28):8605-14.

91. Poynard T, Ratziu V, McHutchison J, Manns M, Goodman Z, Zeuzem S, Younossi Z, Albrecht J. Effect of treatment with peginterferon or interferon alfa-2b and ribavirin on steatosis in patients infected with hepatitis C. Hepatology (Baltimore, Md). 2003;38(1):75-85.

92. Itoh Y, Nishimura T, Yamaguchi K, Yokomizo C, Fujii H, Minami M, Nagao Y, Sumida $Y$, Hashimoto H, Umemura A, et al. Hepatic steatosis in chronic hepatitis $C$ patients infected with genotype 2 is associated with insulin resistance, hepatic fibrosis and affects cumulative positivity of serum hepatitis C virus RNA in peginterferon and ribavirin combination therapy. Hepatology Research: the Official Journal of the Japan Society of Hepatology. 2011;41(12):1145-52.

93. Rafi H, Kabbaj N, Salihoun M, Amrani L, Acharki M, Guedira M, Nya M, Amrani N. Influence of steatosis on progression of fibrosis and virological response in chronic hepatitis C cases. Arab Journal of Gastroenterology: The Official Publication of the Pan-Arab Association of Gastroenterology. 2011;12(3):136-8.

94. Shah SR, Patel K, Marcellin P, Foster GR, Manns M, Kottilil S, Healey L, Pulkstenis E, Subramanian GM, McHutchison JG, et al. Steatosis is an independent predictor of relapse following rapid virologic response in patients with HCV genotype 3. Clinical Gastroenterology and Hepatology: The Official Clinical Practice Journal of the American Gastroenterological Association. 2011;9(8):688-93.

95. Aziz H, Gill U, Raza A, Gill ML. Metabolic syndrome is associated with poor treatment response to antiviral therapy in chronic hepatitis $C$ genotype 3 patients. Eur J Gastroenterol Hepatol. 2014;26(5):538-43.

96. Eslam M, Aparcero R, Kawaguchi T, Del Campo JA, Sata M, Khattab MA, Romero-Gomez M. Meta-analysis: insulin resistance and sustained virological response in hepatitis C. Aliment Pharmacol Ther. 2011;34(3):297-305.

97. Lim T. Metabolic syndrome in chronic hepatitis $C$ infection: does it still matter in the era of directly acting antiviral therapy? Hepatic Medicine: Evidence and Research. 2014;6:113-8.

98. Elgouhari HM, Zein CO, Hanouneh I, Feldstein AE, Zein NN. Diabetes mellitus is associated with impaired response to antiviral therapy in chronic hepatitis C infection. Dig Dis Sci. 2009;54(12):2699-705.

99. Torriani FJ, Rodriguez-Torres M, Rockstroh JK, Lissen E, Gonzalez-Garcia J, Lazzarin A, Carosi G, Sasadeusz J, Katlama C, Montaner J, et al. Peginterferon Alfa-2a plus ribavirin for chronic hepatitis C virus infection in HIV-infected patients. N Engl J Med. 2004;351(5):438-50.
100. Naggie S, Cooper C, Saag M, Workowski K, Ruane P, Towner WJ, Marks K, Luetkemeyer A, Baden RP, Sax PE, et al. Ledipasvir and Sofosbuvir for HCV in Patients Coinfected with HIV-1. N Engl J Med. 2015;373(8):705-13.

101. Wyles DL, Ruane PJ, Sulkowski MS, Dieterich D, Luetkemeyer A, Morgan TR, Sherman KE, Dretler R, Fishbein D, Gathe Jr JC, et al. Daclatasvir plus Sofosbuvir for HCV in Patients Coinfected with HIV-1. N Engl J Med. 2015;373(8):714-25.

102. Rockstroh JK, Nelson M, Katlama C, Lalezari J, Mallolas J, Bloch M, Matthews GV, Saag MS, Zamor PJ, Orkin C, et al. Efficacy and safety of grazoprevir (MK-5172) and elbasvir (MK-8742) in patients with hepatitis C virus and HIV Co-infection (C-EDGE CO-INFECTION): a non-randomised, open-label trial. The lancet HIV. 2015;2(8):e319-27.

103. Collins JM, Raphael KL, Terry C, Cartwright EJ, Pillai A, Anania FA, Farley MM. Hepatitis B Virus Reactivation During Successful Treatment of Hepatitis C Virus With Sofosbuvir and Simeprevir. Clinical Infectious Diseases: an Official Publication of the Infectious Diseases Society of America. 2015;61(8):1304-6.

104. De Monte A, Courjon J, Anty R, Cua E, Naqvi A, Mondain V, Cottalorda J, Ollier L, Giordanengo V. Direct-acting antiviral treatment in adults infected with hepatitis C virus: Reactivation of hepatitis B virus coinfection as a further challenge. Journal of Clinical Virology: The Official Publication of the Pan American Society for Clinical Virology. 2016;78:27-30.

105. Liu CJ, Chen PJ. Updates on the treatment and outcomes of dual chronic hepatitis C and B virus infection. World J Gastroenterol. 2014;20(11):2955-61.

106. Takayama H, Sato T, Ikeda F, Fujiki S. Reactivation of hepatitis B virus during interferon-free therapy with daclatasvir and asunaprevir in patient with hepatitis B virus/hepatitis C virus co-infection. Hepatology Research: The Official Journal of the Japan Society of Hepatology. 2016;46(5):489-91.

107. Tachi Y, Hirai T, Miyata A, Ohara K, lida T, Ishizu Y, Honda T, Kuzuya T, Hayashi K, Ishigami M, et al. Progressive fibrosis significantly correlates with hepatocellular carcinoma in patients with a sustained virological response. Hepatology Research: The Official Journal of the Japan Society of Hepatology. 2015;45(2):238-46.

108. Poynard T, Moussalli J, Munteanu M, Thabut D, Lebray P, Rudler M, Ngo Y, Thibault V, Mkada H, Charlotte F, et al. Slow regression of liver fibrosis presumed by repeated biomarkers after virological cure in patients with chronic hepatitis C. J Hepatol. 2013;59(4):675-83.

\section{Submit your next manuscript to BioMed Central and we will help you at every step:}

- We accept pre-submission inquiries

- Our selector tool helps you to find the most relevant journal

- We provide round the clock customer support

- Convenient online submission

- Thorough peer review

- Inclusion in PubMed and all major indexing services

- Maximum visibility for your research

Submit your manuscript at www.biomedcentral.com/submit
Biomed Central 